\title{
Co-circulation of influenza A(H1N1)pdm09 and influenza A(H3N2) viruses, World Health Organization (WHO) European Region, October 2018 to February 2019
}

Hannah Segaloff', Angeliki Melidou², Cornelia Adlhoch ${ }^{2}$, Dmitriy Pereyaslov¹, Emmanuel Robesyn², Pasi Penttinen², Sonja J

Olsen ${ }^{1}$, WHO European Region and the European Influenza Surveillance Network ${ }^{3}$

1. World Health Organization (WHO) Regional Office for Europe, Copenhagen, Denmark

2. European Centre for Disease Prevention and Control (ECDC), Stockholm, Sweden

3. The members of the network are listed at the end of the article

Correspondence: Sonja J.Olsen (OlsenS@who.int)

Citation style for this article:

Segaloff Hannah, Melidou Angeliki, Adlhoch Cornelia, Pereyaslov Dmitriy, Robesyn Emmanuel, Penttinen Pasi, Olsen Sonja J, WHO European Region and the European Influenza Surveillance Network. Co-circulation of influenza $\mathrm{A}\left(\mathrm{H}_{1} \mathrm{~N}_{1}\right)$ pdmog and influenza $\mathrm{A}\left(\mathrm{H}_{3} \mathrm{~N}_{2}\right)$ viruses, World Health Organization (WHO) European Region, October 2018 to February 2019. Euro Surveill. 2019;24(9):pii=1900125. https://doi.org/10.2807/1560-7917.ES.2019.24.9.1900125

Article submitted on 17 Feb 2019 / accepted on 26 Feb 2019 / published on 28 Feb 2019

In the World Health Organization European Region, the 2018/19 influenza season started in week 492018 , crossing $10 \%$ virus-positivity in sentinel surveillance specimens. At week 5 2019, activity remained elevated with positivity rates at $55 \%$. Both $\mathrm{A}\left(\mathrm{H}_{1} \mathrm{~N}_{1}\right)$ pdmog and $A\left(\mathrm{H}_{3} \mathrm{~N}_{2}\right)$ viruses circulated widely and detection levels in primary care and hospital settings were similar to past seasons. Hospitalisation data may suggest an increased susceptibility to $A\left(\mathrm{H}_{1} \mathrm{~N}_{1}\right)$ pdmog virus in older age groups.

The influenza season in 2018/19 in the World Health Organization European Region has been elevated for 9 weeks, with both influenza A viruses circulating, but the distribution of viruses differs greatly by country. Severity seems similar to past years that have had cocirculating influenza A viruses. Preliminary analyses of data from hospitalised influenza cases may suggest some increase in susceptibility to $A\left(\mathrm{H}_{1} \mathrm{~N}_{1}\right)$ pdmog virus in older age groups.

\section{Influenza surveillance in the European Region}

Every week, 50 of 53 Member States (MS) of the World Health Organization (WHO) European Region and Kosovo*report epidemiological and virological influenza surveillance data to the European Surveillance System (TESSy), hosted by the European Centre for Disease Prevention and Control (ECDC). Analyses of these data during the influenza season (weeks 20 to 40) are published jointly with the WHO Regional Office for Europe in a weekly influenza update, FluNewsEurope [1]. Influenza surveillance is primarily based on primary care sentinel sites collecting specimens from patients with acute respiratory infection
(ARI) and/or influenza like illness (ILI) [2]. A subset of countries conducts surveillance of hospitalised influenza or respiratory infections. Here, we present data from week 40 (starting 1 October 2018) through week 5 (ending 3 February 2019). Data analysis of detected viruses, hospitalised cases and severe acute respiratory infection (SARI) includes cases reported to TESSy as at 11 February 2019; genetic and antigenic characterisation and antiviral resistance data are provided as at 7 February 2019.

\section{Start of the 2018/19 influenza season and activity as at 3 February}

Influenza activity started to increase in early December (week 49 2018) and has continued into early February (week 5 2019); during these 9 weeks, more than $10 \%$ of the sentinel ARI/ILI specimens were positive for influenza (i.e. $10 \%$ threshold).

In the $2018 / 19$ season, the $10 \%$ threshold was crossed 1 week later than in the B-dominated 2017/18 influenza season, 3 weeks later than the $\mathrm{A}\left(\mathrm{H}_{3} \mathrm{~N}_{2}\right)$-dominated 2016/17 season and 2 weeks before the previous influenza $A\left(\mathrm{H}_{1} \mathrm{~N}_{1}\right)$ pdmo9-dominated season of $2015 / 16$. In addition, percent specimen positivity in week 52019 was $55 \%$, comparable to what was observed during the past two seasons (Figure 1) [3,4].

The increase in influenza activity was first reported in the eastern part of the Region, with Georgia, Kyrgyzstan and Ukraine reporting medium influenza intensity by week 49 2018. These increases coincided with a steep rise in influenza virus detections from hospitalised SARI cases, with all three countries reporting over $50 \%$ percent positivity in week 50 2018. In Georgia 
Percentage of sentinel ILI/ARI specimens testing positive for influenza, by season, 50 World Health Organization European Region Member States and Kosovo ${ }^{*}$, influenza seasons 2014/15-2018/19

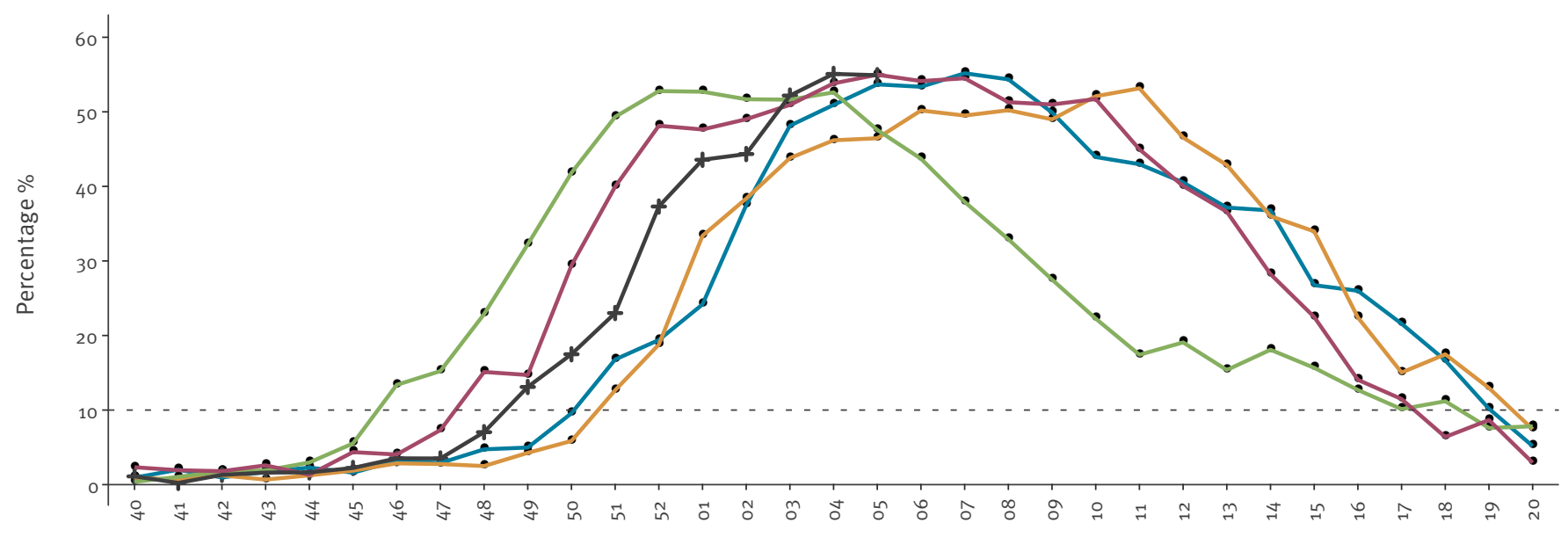

Week

$$
\begin{aligned}
& \text { - 2014/15; 67\% A }\left(77 \% \mathrm{H}_{3}\right) \\
& \text { - 2016/17; 89\% A (99\% H3) - 2018/19; } 99 \% \mathrm{~A}\left(58 \% \mathrm{H}_{1}\right) \\
& \text { - 2015/16; } 56 \% \text { A }\left(86 \% \mathrm{H}_{1}\right) \\
& \text { - 2017/18; } 37 \% \text { A }\left(65 \% \mathrm{H}_{1}\right)
\end{aligned}
$$

ARI: acute respiratory infection; ILI: influenza-like illness.

Legend depicts seasons, percentage of sentinel detections that were influenza A and prevalence of most common influenza A subtype among all subtyped A viruses.

*This designation is without prejudice to positions on status, and is in line with United Nations Security Council Resolution $1244 / 99$ and the International Court of Justice Opinion on the Kosovo Declaration of Independence.

and Kyrgyzstan detections were almost all influenza $A\left(\mathrm{H}_{1} \mathrm{~N}_{1}\right)$ pdmo9, but in Ukraine $\mathrm{A}\left(\mathrm{H}_{3} \mathrm{~N}_{2}\right)$.

Influenza activity has continued to intensify across the Region. In week 5 2019, the median positivity of sentinel specimens by MS was $57 \%$ with several countries, particularly in the southern and eastern part of the Region, reporting it as an intense influenza season. Turkey and Israel (countries where influenza $\mathrm{A}\left(\mathrm{H}_{3} \mathrm{~N}_{2}\right)$ viruses circulated predominantly), reported weekly consultation rates for ILI exceeding those of the previous two seasons (2016/17 and 2017/18). Georgia and Albania, who had influenza $\mathrm{A}\left(\mathrm{H}_{1} \mathrm{~N}_{1}\right)$ pdmog viruses circulating predominantly, observed more SARI cases and higher percent positivity for influenza than in previous seasons. While in most countries reported activity was increasing or levelling off in week 5 2019, some countries in the southern and eastern European Region reported decreasing activity.

\section{Virology}

\section{Influenza A}

As at week 5 2019, 58\% of all 7,437 subtyped influenza $A$ viruses were influenza $A\left(\mathrm{H}_{1} \mathrm{~N}_{1}\right)$ pdmog and $42 \%$ were influenza $\mathrm{A}\left(\mathrm{H}_{3} \mathrm{~N}_{2}\right)$ among influenza cases detected though general practitioner sentinel systems; distribution of circulating influenza A subtypes varied by country (Figure 2). Influenza $A\left(\mathrm{H}_{1} \mathrm{~N}_{1}\right)$ pdmog and $A\left(\mathrm{H}_{3} \mathrm{~N}_{2}\right)$ co-infections were reported and a seasonal reassortant influenza $A\left(\mathrm{H}_{1} \mathrm{~N}_{2}\right)$ virus was detected in Sweden [5].

As at week 5 2019, all 767 antigenically characterised $\mathrm{A}\left(\mathrm{H}_{1} \mathrm{~N}_{1}\right) \mathrm{pdmog}$ viruses were similar to the season's vaccine virus, A/Michigan/45/2015. All of the 826 genetically characterised $\mathrm{A}\left(\mathrm{H}_{1} \mathrm{~N}_{1}\right)$ pdmog viruses belonged to subgroup 6B.1 represented by A/Michigan/45/2015. The majority $(68 \% ; n=78)$ of antigenically characterised $\mathrm{A}\left(\mathrm{H}_{3} \mathrm{~N}_{2}\right)$ viruses were similar to this season's vaccine virus A/Singapore/INFIMH-16-0019/2016. Genetically, $81 \%(n=432)$ belonged to clade 3 C.2a and of these, the majority $(83 \% \mathrm{n}=358)$ were in the 3 C.2a1b group. Viruses belonging to clade 3 C.3a were reported by some countries.

\section{Influenza B}

Given the low prevalence, few influenza B viruses were genetically or antigenically characterised. All four B/ Yamagata viruses antigenically characterised were similar to the quadrivalent vaccine virus and assigned to clade B/Phuket/3072/2013 of the quadrivalent vaccine virus. Three of four antigenically characterised B/ 


\section{FIGURE 2}

Distribution of dominant patterns of influenza virus type circulating, World Health Organization European Region, week 40 2018-week 52019

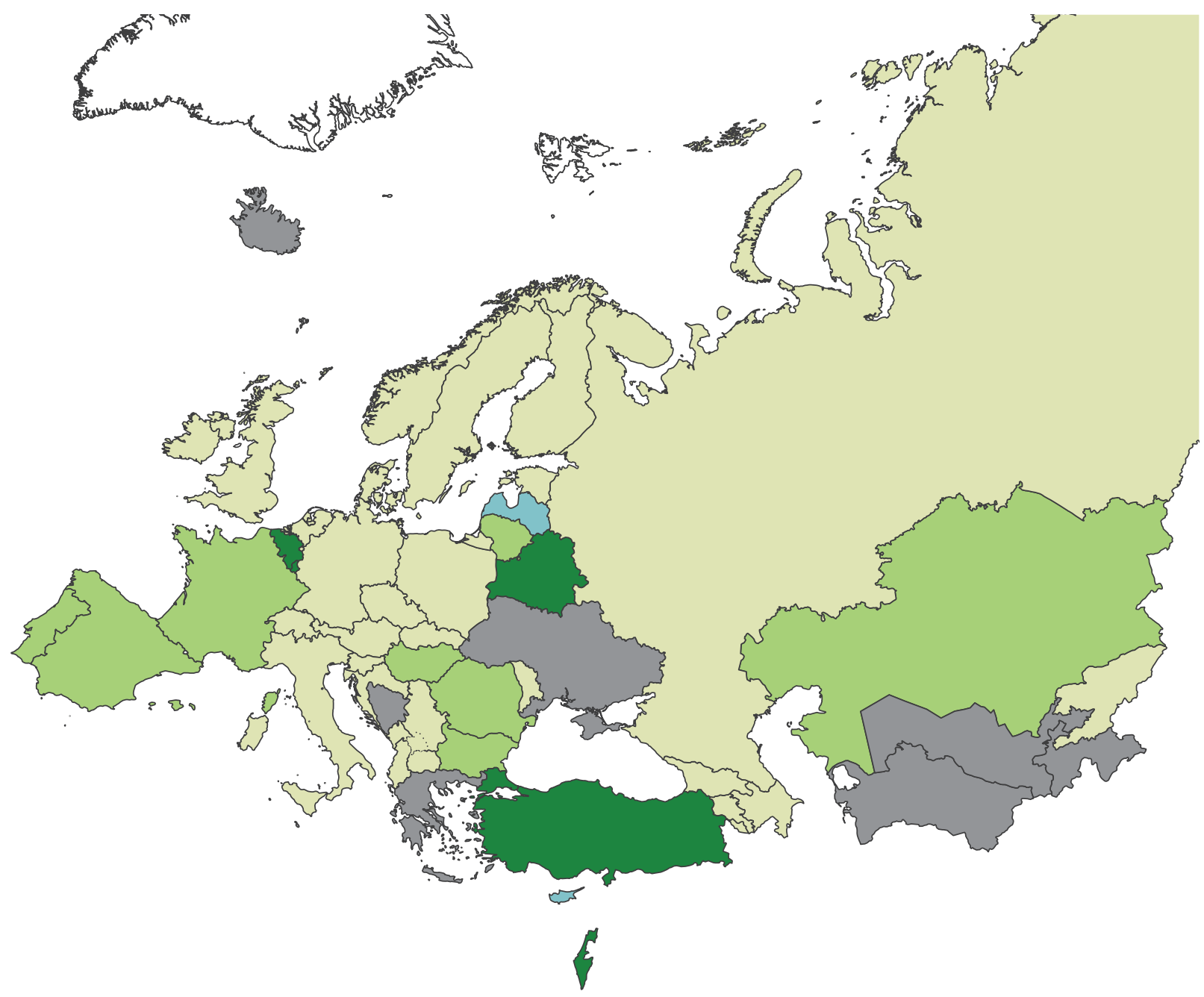

Dominant virus type (sentinel detections)

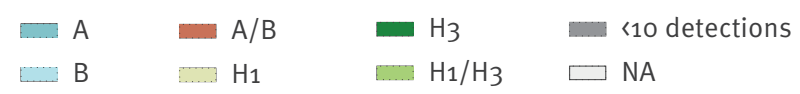

Dominance of virus type/subtype is based on at least $60 \%$ of influenza virus detections from sentinel surveillance and co-dominance is based on between $40 \%$ and $60 \%$. Calculations only considered valid if at least 10 viruses were detected from sentinel systems.

Victoria viruses were similar to the trivalent influenza $B$ vaccine virus. Among the $12 \mathrm{~B} /$ Victoria lineage viruses genetically characterised, 4 of 12 were assigned to the $\mathrm{B} /$ Colorado/o6/2017 group containing the trivalent vaccine virus ( $\mathrm{HA}_{1}$ double amino acid deletion, $\Delta 162-163)$ and 5 of 12 were assigned to the $B /$ Hong Kong/269/2017 group (HA1 triple amino acid deletion, $\Delta 162-164)$. These triple deletion viruses are antigenically distinct from the vaccine virus and few have previously been detected.

\section{Neuraminidase inhibitor susceptibility}

Neuraminidase inhibitor susceptibility was assessed for 897 viruses $\left(A\left(\mathrm{H}_{1} \mathrm{~N}_{1}\right)\right.$ pdmog $=602, \mathrm{~A}\left(\mathrm{H}_{3} \mathrm{~N}_{2}\right)=283$; $B=12)$. Three $A\left(H_{1} N_{1}\right)$ pdmog viruses carried amino acid substitution $\mathrm{H}_{2} 75 \mathrm{Y}$ in neuraminiase indicative of highly reduced inhibition by oseltamivir, one $A\left(\mathrm{H}_{3} \mathrm{~N}_{2}\right)$ virus showed evidence of reduced inhibition to oseltamivir and one $B$ virus showed evidence of reduced inhibition to zanamivir in phenotypic tests. 
Numbera , subtype and percent positivity of specimens from severe acute respiratory infection surveillance by season, World Health Organization European Region Member States, influenza season 2014/15-2018/19

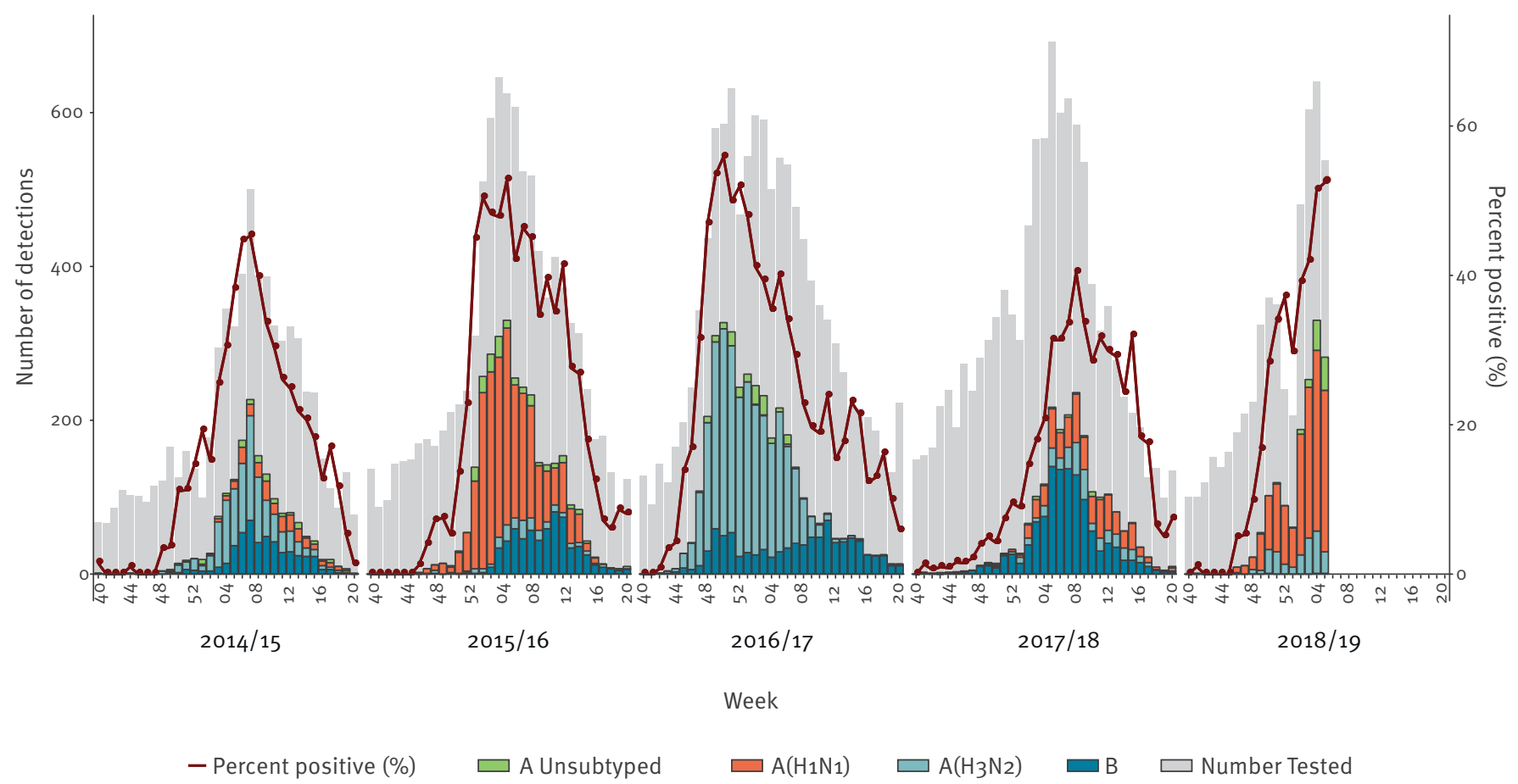

SARI: severe acute respiratory infection; MS: Member State.

${ }^{a}$ Number of countries conducting surveillance for severe acute respiratory infections in hospitalised patients: $2014 / 15$ ( $\left.=12\right), 2015 / 16$ ( $=$ 17), 2016/17 $(n=16), 2017 / 18(n=18)$ and 2018/19 $(n=17)$.

Over the five seasons, data on SARI detections was reported by a subset of MS: Albania, Armenia, Azerbaijan, Georgia, Kyrgyzstan, Kazakhstan, Republic of Moldova, Serbia, Russian Federation and Ukraine for all seasons. For a subset of seasons, data on SARI detections was reported by: Bosnia and Herzegovina, Belgium, Belarus, Cyprus, Montenegro, Tajikistan, Turkmenistan, Uzbekistan and Kosovo*.

* This designation is without prejudice to positions on status, and is in line with United Nations Security Council Resolution $1244 / 99$ and the International Court of Justice Opinion on the Kosovo Declaration of Independence.

\section{Severe acute respiratory infection (SARI) cases}

As at week 5 2019, 17 countries that conduct SARI surveillance reported 23,929 hospitalised cases; $A\left(\mathrm{H}_{1} \mathrm{~N}_{1}\right)$ pdmog virus was detected in $77 \%(1165 / 1521)$ of influenza-positive cases. The total number of SARI detections and percentage of positivity were similar to peak detection and positivity seen in the 2015/16 A(H1N1)dominated and 2016/17 $\mathrm{A}\left(\mathrm{H}_{3} \mathrm{~N}_{2}\right)$-dominated influenza seasons and both the number of cases detected and positivity rates exceeded those seen in $2014 / 15$ or 2017/18 seasons (Figure 3 ).

\section{Laboratory-confirmed influenza in hospitalised patients admitted to the intensive care unit}

As at week 5 2019, 12 countries that conduct casebased surveillance of influenza-positive hospitalisations reported 3,353 influenza-positive cases in persons admitted to the intensive care unit (ICU). Among influenza A viruses subtyped, 68\% (378/555) were influenza $A\left(\mathrm{H}_{1} \mathrm{~N}_{1}\right)$ pdmog and $32 \%$ (177/555) were influenza $A\left(\mathrm{H}_{3} \mathrm{~N}_{2}\right) ; 63 \%(956 / 1,511)$ of viruses were not subtyped. Compared with the $2014 / 15$ season when both viruses also co-circulated, in 2018/19 the proportion of $A\left(\mathrm{H}_{1} \mathrm{~N}_{1}\right)$ pdmog infected patients aged $24-44$ years increased from 12 to $16 \%$ and that of patients aged $65-74$ years from $21 \%$ to $27 \%$ (Figures 4 ). In contrast, the proportion of $\mathrm{A}\left(\mathrm{H}_{3} \mathrm{~N}_{2}\right)$ infected patients aged 45-64 years (24-32\%) increased.

\section{Discussion and conclusions}

Influenza activity in the WHO European Region has been high and increasing since early December (week 49 2018). As at 11 February 2019, the 2018/19 influenza season was dominated by influenza $A$ viruses; both subtypes were co-circulating with a slight dominance of influenza $A\left(\mathrm{H}_{1} \mathrm{~N}_{1}\right)$ pdmo9. Compared with past seasons dominated by influenza either $A\left(\mathrm{H}_{1} \mathrm{~N}_{1}\right)$ pdmog or $\mathrm{A}\left(\mathrm{H}_{3} \mathrm{~N}_{2}\right)\left(2014 / 15^{-2016 / 17)}\right.$, the current season has been similarly intense and SARI data suggest similar 


\section{FIGURE 4}

Age group distribution for influenza $\mathrm{A}(\mathrm{H} 1 \mathrm{~N} 1) \mathrm{pdm} 09$ and $\mathrm{A}(\mathrm{H} 3 \mathrm{~N} 2)$ cases in the intensive care unit in the (A) 2018/19 and (B) 2014/15 influenza seasons, World Health Organization European Region Member States

\section{A. 2018/19 influenza season}
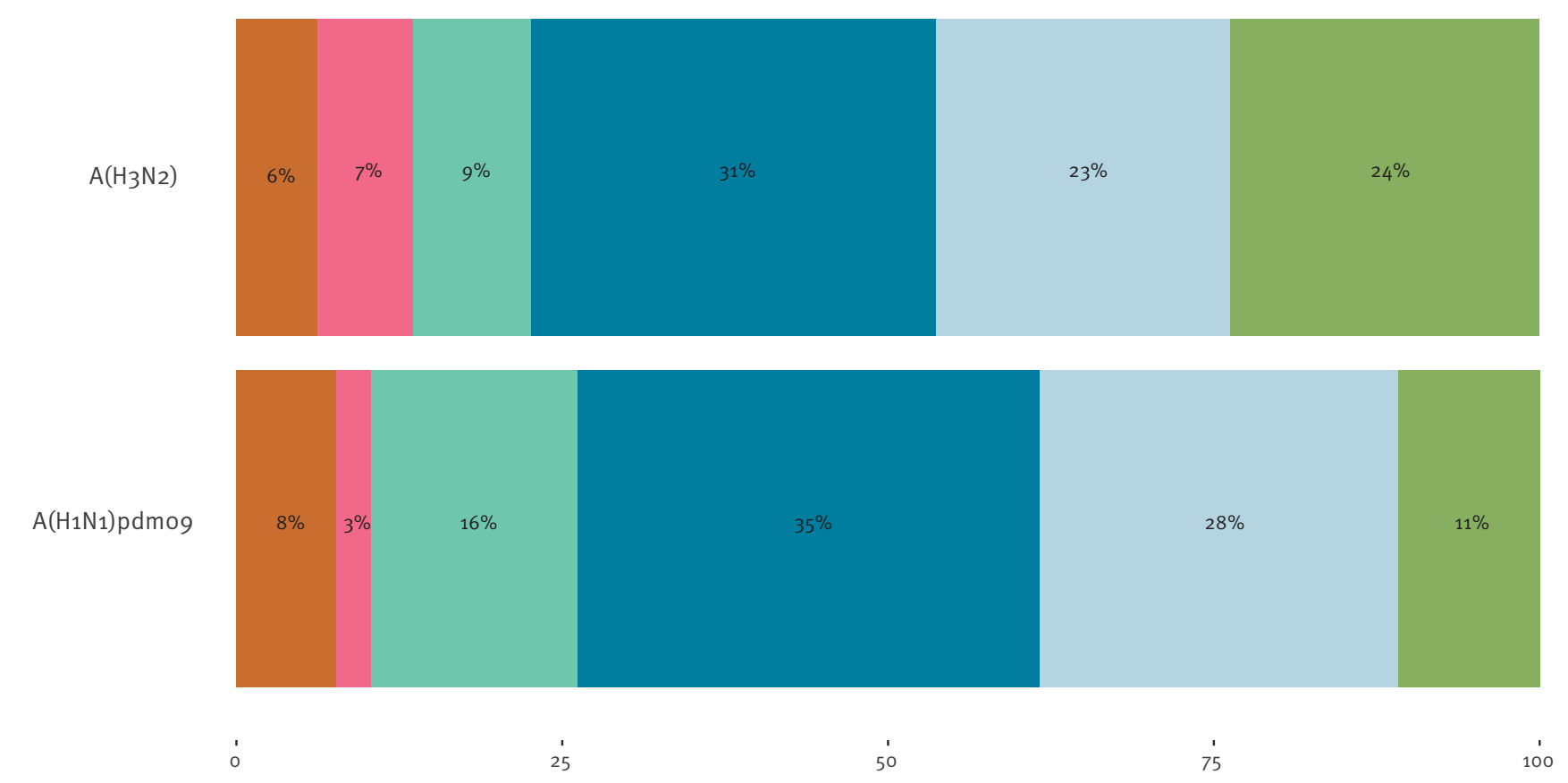

Percent of detections from each age group (\%)

\section{B. 2014/15 influenza season}
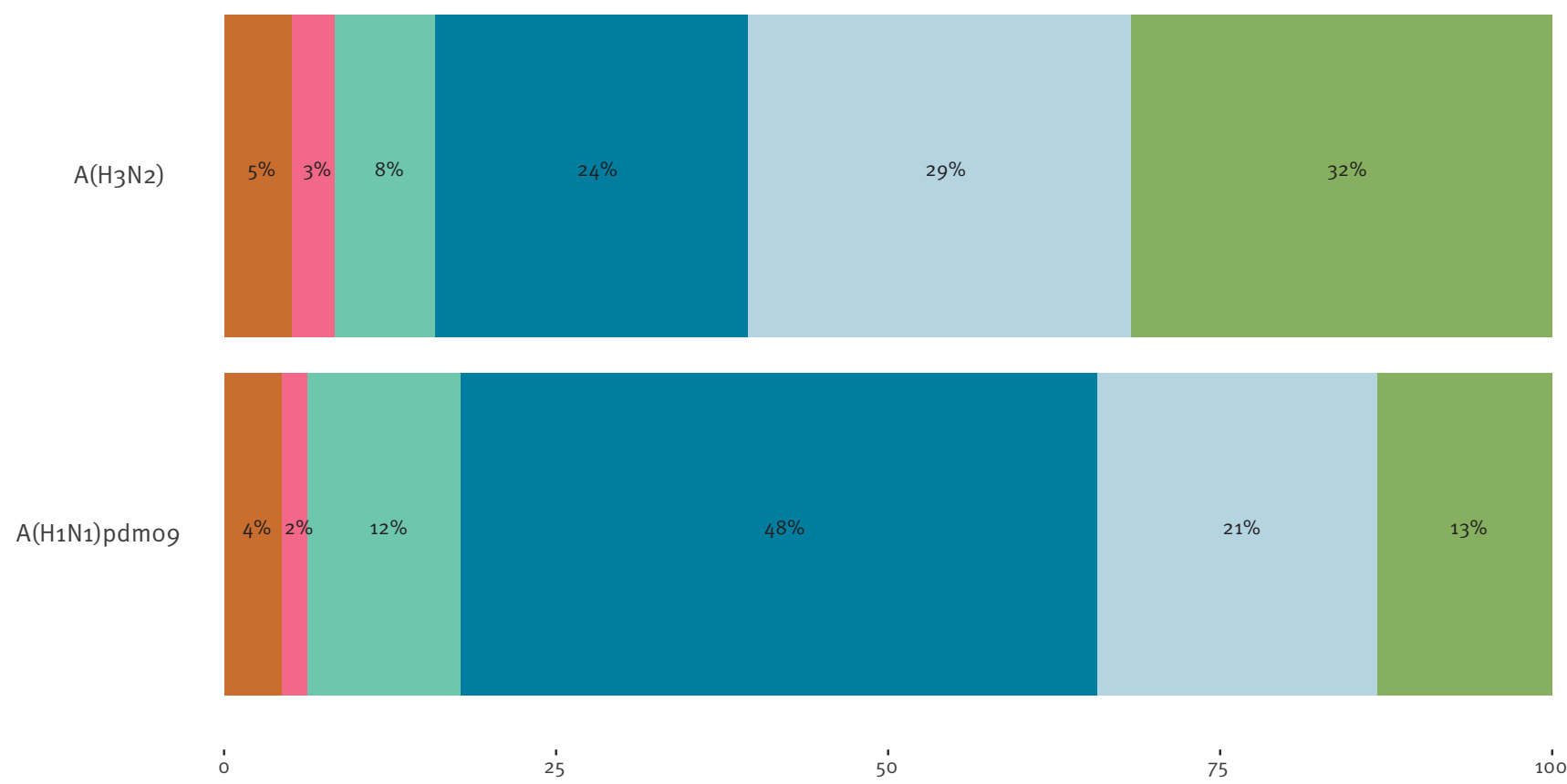

Percent of detections from each age group (\%)

\section{Age Group}

$\begin{array}{lll}>74 & 45-64 & 5-24 \\ 65-74 & 25-44 & 0-4\end{array}$

Data on influenza-positive hospitalisations in the intensive care unit is collected by a subset of Member States; in $2014 / 15$ data was reported by Denmark, Estonia, Finland, France, Ireland, Romania, Sweden and Slovakia. In 2018/19 the Czech Republic, Estonia, Russia and Ukraine also reported data and Slovakia did not provide data. 
severity (although SARI data are only collected from a subset of countries in eastern Europe).

This is the tenth influenza season with circulation of $\mathrm{A}\left(\mathrm{H}_{1} \mathrm{~N}_{1}\right)$ pdmog virus since its initial appearance during the 2009 pandemic. Influenza $A\left(\mathrm{H}_{1} \mathrm{~N}_{1}\right)$ pdmog seasons affect younger adults more severely; an estimated $65 \%$ of deaths from the first 12 months of the pandemic were in persons 18-64 [6]. In contrast, $\mathrm{A}\left(\mathrm{H}_{3} \mathrm{~N}_{2}\right)$ affects adults 65 years and older more; about $80-90 \%$ of deaths from $\mathrm{A}\left(\mathrm{H}_{3} \mathrm{~N}_{2}\right)$ occur in this age group $[7,8]$. As expected, among hospitalised patients in ICUs, we saw these age differences between influenza $A\left(\mathrm{H}_{1} \mathrm{~N}_{1}\right)$ pdmog and influenza $\mathrm{A}\left(\mathrm{H}_{3} \mathrm{~N}_{2}\right)$ cases. Personsaged 75 years and older accounted for a higher proportion of influenza $\mathrm{A}\left(\mathrm{H}_{3} \mathrm{~N}_{2}\right)$ ICU admissions compared with $\mathrm{A}\left(\mathrm{H}_{1} \mathrm{~N}_{1}\right)$ pdmo9. However, when comparing ICU admissions from the $2014 / 15$ season to the current season, we saw the relative proportion of adults aged 25-44 and 65-74 years increase among $A\left(\mathrm{H}_{1} \mathrm{~N}_{1}\right)$ pdmo9related ICU admissions and the proportion of those aged 45-64 years increase among cases with influenza $\mathrm{A}\left(\mathrm{H}_{3} \mathrm{~N}_{2}\right)$. This changing age-distribution by subtype may, in part, reflect the ageing population of those with pre-pandemic exposure to the 1918-like $A\left(\mathrm{H}_{1} \mathrm{~N}_{1}\right)$ virus, who may have some residual immunologic protection [9]. This might explain the increased proportion of adults aged $65-74$ years among $A\left(\mathrm{H}_{1} \mathrm{~N}_{1}\right)$ pdmo9 detections in the current season, although this subset of data from 12 countries may not be generalisable and these early observations will require further, more rigorous, examination at the end of the season.

The relative proportion of circulating influenza $A\left(\mathrm{H}_{1} \mathrm{~N}_{1}\right)$ pdmog and influenza $\mathrm{A}\left(\mathrm{H}_{3} \mathrm{~N}_{2}\right)$ viruses varied by country and region this season. Recent interim vaccine effectiveness (VE) estimates indicate that the current vaccine is effective at preventing influenza virus infection, particularly by $\mathrm{A}\left(\mathrm{H}_{1} \mathrm{~N}_{1}\right)$ pdmog viruses, in children [10-12]. In recent years, the vaccine was less effective against influenza $A\left(\mathrm{H}_{3} \mathrm{~N}_{2}\right)$ viruses [13]. VE may vary across the Region based on the mix of circulating influenza subtypes and variation within the antigenic likeness of circulating $A\left(\mathrm{H}_{3} \mathrm{~N}_{2}\right)$ viruses with the eggpropagated $\mathrm{A}\left(\mathrm{H}_{3} \mathrm{~N}_{2}\right)$ vaccine component. Despite its limitations, vaccination remains the most effective way to prevent influenza. Circulating influenza viruses during 2018/19 were largely susceptible to the antiviral drugs oseltamivir and zanamivir and these should be used as indicated by national guidelines.

\section{Note}

* For the purposes of this publication, all references, including in the bibliography, to 'Kosovo' should be understood/ read as 'Kosovo (in accordance with Security Council resolution 1244 (1999))'. This designation is without prejudice to positions on status, and is in line with UNSCR $1244 / 1999$ and the ICJ Opinion on the Kosovo declaration of independence.
Members of the WHO European Region and European Influenza Surveillance Network

Albania: Iris Hasibra (Hatibi) and Artan Simaku

Armenia: Liana Torosyan and Shushan Sargsyan

Austria: Monika Redlberger-Fritz and Therese Popow-Kraupp

Azerbaijan: Oleg Salimov and Nazakat Abdullayeva

Belarus: Natallia Shmialiova and Natalia Gribkova

Belgium: Nathalie Bossuyt and Isabell Thomas

Bosnia and Herzegovina: Nina Rodic Vukmir and Diana Bastinac

Bulgaria: Neli Korsun and Anna Kurchatova

Croatia: Goranka Petrović and Vladimir Draženović

Cyprus: Maria Koliou and Despo Pieridou

Czech Republic: Martina Havlíčková and Jan Kynčl

Denmark: Ramona Trebbien and Tyra Grove Krause

France: Sibylle Bernard-Stoecklin and Sylvie van der Werf

Finland: Niina Ikonen and Outi Lyytikäinen

Georgia: Ann Machablishvili and Khatuna Zakhashvili

Germany: Silke Buda and Ralf Dürrwald

Greece: Athanasios Kossyvakis and Maria Exindari

Hungary: Zsuzsanna Molnár and Mónika Rózsa

Ireland: Linda Dunford and Niamh Murphy

Israel: Aharona Glatman-Freedman and Michal Mandelboim

Italy: Antonino Bella and Maria Rita Castrucci

Kazakhstan: Sultanov Meirim and Nussupbayeva Gaukhar

Kyrgyzstan: Otorbaeva Dinagul and Saparova Gulbarchyn

Latvia: Natalija Zamjatina and Raina Nikiforova

Lithuania: Asta Skrickienė and Algirdas Griškevičius

Luxembourg: Guillaume Fournier and Joel Mossong

Malta: Graziella Zahra and Jackie Maistre Melillo

Montenegro: Božidarka Rakočević and Zoran Vratnica

The Netherlands: Ron Fouchier and Adam Meijer

Norway: Olav Hugnes and Karoline Bragstad

Poland: Lidia B. Brydak and Katarzyna Luniewska

Portugal: Raquel Guiomar and Ana Paula Rodrigues

Republic of Moldova: Stefan Gheorghita and Alina Druc

Romania: Rodica Popescu and Odette Popovici

Russian Federation: Anna Sominina and Elena Burtseva 
Serbia: Dragana Dimitrijevic and Svetlana Filipović-Vignjević

Slovenia: Katarina Prosenc and Maja Sočan

Spain: Amparo Larrauri and Francisco Pozo

Sweden: Mia Brytting and AnnaSara Carnahan

Switzerland: Ana Rita Gonçalves and Damir Perisa

Tajikistan: Tamanno Safarova and Niginamo Zakirova

The Republic of North Macedonia: Bosevska Golubinka and Kuzmanovska Maja

Turkey: Emine Avci and Ayse Basak Altas

Turkmenistan: Gurbangul Ovliyakulova and Ashirova Amansoltan

Ukraine: Iryna Demchishina and Oksana Artemchuk

United Kingdom: Jim McMenamin and Maria Zambon

Uzbekistan: Sultana Djemileva and Ravshan Rakhimov

WHO Collaborating Centre London: John McCauley and Rod Daniels

Radboud University Medical Center, The Netherlands: Tamara Meerhoff (WHO consultant)

\section{Acknowledgements}

ECDC and WHO Regional Office for Europe want to thank all data providers and contributing experts in the countries. We are grateful for the support of Marius Valcu at ECDC

Austria: Dalmatiner, Katrin Wiedeschitz and Anreas Rochorzka

Czech Republic: Helena Jirincova, Ludmila Novakova and Dusan Trnka

Denmark: Lisbet Krause Knudsen and Ida Glode Helmuth

Estonia: Surveillance Team

Finland: Hanna Nohynek and Anu Haveri

France: Behillil Sylvi, Blanchon Thierry, Campese Christine, Enouf Vincent, Falchi Alessandra, Launay Titouan, Lina Bruno, Masse Shirley, Turbelin Clement, Valette Martine, Vilcu Ana-Maria, and Villechenaud Natacha

Germany: Sentinel physicians and Viktoria Streib

Iceland: Surveillance Team

Ireland: Sarah Fitzpatrick, Alison Kelly, Joanne Moran, Jeff Connell and Cillian de Gascun and Sarah Jackson, Meadhbh Hunt, Paula Flanagan, Margaret Mclver, Joan O'Donnell, nurses, physicians and scientists in the sentinel network

Israel: Israel: Hanna Sefty, Rakefet Pando

Italy: Simona Puzelli, Angela Di Martino, Marzia Facchini, Stefania Giannitelli, Caterina Rizzo, Bambino Gesù, Sentinel General Practitioners and Regional Laboratory Network for influenza (InfluNet)

Kazakhstan: Smagulova Meiramgul
Kosovo: Surveillance Team

Luxembourg: Nguyen Trung Nguyen

Malta: Barbara Christopher, Tanya Melillo, Graziella Zahra and Jackie Maistre Melillo

Netherlands: Anne Teirlinck, Daphne Reukers, Marit de Lange, Wim van der Hoek, Mariam Bagheri, Sharon van den Brink, Gabriel Goderski, Ton Marzec, Pieter Overduin, Elsa Poorter, Lisa Wijsman, Ge Donker, Mariette Hooiveld, Nivel, Mark Pronk and Ruud van Beek

Norway: Ragnhild Tønnessen, Trine Hessevik Paulsen, Torstein Aune, Kristian Waalen, Siri Hauge, technical staff, general practitioners and microbiology laboratories

Portugal: Inês Costa, Paula Cristóvão, Patrícia Conde, Pedro Pechirra, Verónica Gomez, Ana Rita Torres, Ausenda Machado and General Practitioner Sentinel Network; Emergency and Obstetric t Network, Portuguese Laboratory Network for Influenza Diagnosis and the EuroEVA network

Romania: Mihaela Lazar

Russia: Daria Danilenko and Andrey Komissarov

Slovakia: Surveillance Team

Slovenia: Nataša Berginc and Vesna Šubelj

Spain: Inmaculada Casas, Concha Delgado-Sanz, Jesús Oliva, Raul Ortiz de Lejarazu, Ma Ángeles Marco and members of the Spanish Influenza Surveillance System (SISS).

The Republic of North Macedonia: Mikikj Vladimir, national sentinel ILI and SARI network

Ukraine: Tetyana Dykhanovska, Alla Mironenko, Liudmyla Leibenko, Larysa Radchenko, Olha Holubka

United Kingdom: Richard Pebody, Simon Cottrell, Catherine Moore, Mark O'Doherty, Jillian Johnson, Arlene Reynolds, Samantha Shepherd, Rory Gunson, Simon de Lusignan, Joanna Ellis, Monica Galiano, Catherine Thompson, Alasdair Maclean and Catherine Frew.

WHO Regional Office for Europe was supported to work on influenza by a cooperative agreement from the Unites States Centers for Disease Control and Prevention (NU511Po00876); the funder had no role in the analysis or interpretation of the data.

Disclaimer: The authors alone are responsible for the views expressed in this article and they do not necessarily represent the views, decisions or policies of the institutions with which they are affiliated. Maps used in this paper do not imply any opinions on the part of ECDC and WHO or its partners about the legal status of the countries and territories shown or about their borders.

\section{Conflict of interest}

None declared.

\section{Authors' contributions}

H Segaloff: influenza surveillance data maintenance, data analysis and draft of the manuscript; A Melidou, C Adlhoch, D. Pereyaslov and E Robesyn: influenza surveillance data maintenance and analysis review of the manuscript; $P$ 
Penttinen and SJ Olsen: surveillance strategy, critical review of the manuscript; surveillance network: collection and analysis of country data, critical review of the manuscript.

\section{References}

1. European Centre for Disease Prevention and Control (ECDC) World Health Organization Regional Office for Europe (WHO/ Europe). Flu News Europe, Joint ECDC-WHO weekly influenza update 2019. Stockholm/Geneva: ECDC-WHO/Europe; [Accessed February 11]. Available from: www.flunewseurope. org

2. World Health Organization Regional Office for Europe/ European Centre for Disease Prevention and Control (WHO/ECDC). Influenza Surveillance Country, Territory and Area Profiles 2017. Copenhagen/Stockholm:

WHO/ECDC; 2017. Available from: http://www.

euro.who.int/__data/assets/pdf_file/0007/356119/ InfluenzaSurveillanceProfiles_2017_en.pdf

3. European Centre for Disease Prevention and Control (ECDC). Annual Epidemiological Report 2016-Seasonal Influenza. Stockholm: ECDC; 2016. Available from: https://ecdc. europa.eu/en/publications-data/seasonal-influenza-annualepidemiological-report-2016-17-season

4. Adlhoch C, Snacken R, Melidou A, Ionescu S, Penttinen PThe European Influenza Surveillance Network. Dominant influenza $\mathrm{A}\left(\mathrm{H}_{3} \mathrm{~N}_{2}\right)$ and $\mathrm{B} /$ Yamagata virus circulation in $\mathrm{EU} /$ EEA, 2016/17 and 2017/18 seasons, respectively. Euro Surveill. 2018;23(13):18-00146. https://doi.org/10.2807/1560-7917. ES.2018.23.13.18-00146 PMID: 29616611

5. Public health Agency Sweden (PHAS). Influensarapport vecka 3 Sasongen 2018-2019. [Influenza report week 3 Season 2018-2019]. Stockholm: PHAS; 2019. Swedish. Available from: https://www.folkhalsomyndigheten.se/globalassets/ statistik-uppfoljning/smittsamma-sjukdomar/veckorapporterinfluensa/2018-2019/influensarapport-2019-03.pdf

6. Dawood FS, luliano AD, Reed C, Meltzer MI, Shay DK, Cheng PY, et al. Estimated global mortality associated with the first 12 months of 2009 pandemic influenza $\mathrm{A} \mathrm{H}_{1} \mathrm{~N}_{1}$ virus circulation: a modelling study. Lancet Infect Dis. 2012;12(9):687-95. https:// doi.org/10.1016/S1473-3099(12)70121-4 PMID: 22738893

7. Thompson WW, Shay DK, Weintraub E, Brammer L, Cox $\mathrm{N}$, Anderson LJ, et al. Mortality associated with influenza and respiratory syncytial virus in the United States. JAMA. 2003;289(2):179-86. https://doi.org/10.1001/jama.289.2.179 PMID: 12517228

8. Nielsen J, Vestergaard LS, Richter L, Schmid D, Bustos N, Asikainen T, et al. European all-cause excess and influenzaattributable mortality in the $2017 / 18$ season: should the burden of influenza B be reconsidered? Clin Microbiol Infect. 2019;S1198-743X(19)30058-8. Forthcoming.

9. Hancock K, Veguilla V, Lu X, Zhong W, Butler EN, Sun H, et al. Cross-reactive antibody responses to the 2009 pandemic $\mathrm{H}_{1} \mathrm{~N}_{1}$ influenza virus. N Engl J Med. 2009;361(20):1945-52. https:// doi.org/10.1056/NEJMoa0906453 PMID: 19745214

10. Skowronski DM, Leir S, Sabaiduc S, Murti M, Dickinson JA, Olsha $R$, et al. Interim estimates of $2018 / 19$ vaccine effectiveness against influenza $A\left(\mathrm{H}_{1} \mathrm{~N}_{1}\right)$ pdmo9, Canada, January 2019. Euro Surveill. 2019;24(4):1900055. https:// doi.org/10.2807/1560-7917.ES.2019.24.4.1900055 PMID: 30696523

11. Chiu SS, Kwan MY, Feng S, Chan EL, Chua H, Wong JS, et al. Early season estimate of influenza vaccination effectiveness against influenza hospitalisation in children, Hong Kong, winter influenza season 2018/19. Euro Surveill. 2019;24(5):1900056. https://doi.org/10.2807/1560-7917. ES.2019.24.5.1900056 PMID: 30722814

12. Doyle JD, Chung JR, Kim SS, Gaglani M, Raiyani C, Zimmerman RK, et al. Interim Estimates of 2018-19 Seasonal Influenza Vaccine Effectiveness - United States, February 2019. MMWR Morb Mortal Wkly Rep. 2019;68(6):135-9. https://doi. org/10.15585/mmwr.mm6806a2 PMID: 30763298

13. Belongia EA, Simpson MD, King JP, Sundaram ME, Kelley NS, Osterholm MT, et al. Variable influenza vaccine effectiveness by subtype: a systematic review and meta-analysis of testnegative design studies. Lancet Infect Dis. 2016;16(8):94251. https://doi.org/10.1016/S1473-3099(16)00129-8 PMID: 27061888

\section{License, supplementary material and copyright}

This is an open-access article distributed under the terms of the Creative Commons Attribution (CC BY 4.0) Licence. You may share and adapt the material, but must give appropriate credit to the source, provide a link to the licence and indicate if changes were made.

Any supplementary material referenced in the article can be found in the online version.

This article is copyright of the authors or their affiliated institutions, 2019. 